\title{
Effect of Dodine Acetate on the Electrophoretic Mobility of Neurospora crassa Conidia
}

\author{
By E. SOMERS* AND D. J. FISHER \\ Long Ashton Research Station, University of Bristol
}

(Accepted for publication 23 February 1967)

SUMMARY

The electrokinetic behaviour of intact conidia and cell walls of Neurospora crassa was studied using a micro-electrophoresis technique. By chemical and enzyme treatments it has been established that amino, carboxyl and phosphate groups are integral components of the spore surface; acid phosphate groups, however, were not found on the surface of washed cell walls. The fungicide dodine acetate reduced the negative charge on conidia to zero and, with increasing concentration, gave a positive charge to the spores: at lower fungicide concentrations the negative charge on the surface of cell walls and stabilized protoplasts was also neutralized. These results are consistent with an ionic reaction between the dodine cation and the carboxyl and phosphate groups of the cell. There was no evidence that the toxic reaction between dodine acetate and $N$. crassa conidia is located on the spore surface-the spores were completely killed before there was a perceptible reduction in electrophoretic mobility.

\section{INTRODUCTION}

Although the electrophoretic properties of bacteria and erythrocytes have been extensively investigated, little attention has been given to fungi, except for yeasts. The only studies on fungal spores are those of Douglas, Collins \& Parkinson (1959) and Hannan (1961). Their work has shown that spores, in common with other microorganisms, bear a negative charge over a wide $\mathrm{pH}$ range of suspending medium, the nature of the ionogenic groups on the spore surface varying with the fungal species. The electrokinetic behaviour of fungal spores deserves study not only to determine the nature of the ionized, or ionizable, surface groups but also because it is with these groups that the initial reaction with a fungicide-which may be an ionic speciesoccur.

The surface-active agents toxic to micro-organisms are those which are ionic in character and their reaction at the cell surface can be followed very conveniently by micro-electrophoretic techniques-as has been shown by work on bacteria (James, 1965). Dodine acetate ( $n$-dodecylguanidine acetate) is a well-established agricultural fungicide: chemically, it has the structure of a cationic surface-active agent and its accumulation by fungal conidia follows, in general, an ionic bonding pattern (Somers \& Pring, 1966). The interaction between dodine acetate and the spore surface has been investigated by the micro-electrophoresis of the intact conidia, protoplasts, and cell walls of Neurospora crassa. Particular attention has been given to the nature of the charged groups present on the spore surface with which dodine acetate reacts.

\footnotetext{
* Present address: Food and Drug Directorate, Tunny's Pasture, Ottawa 3, Canada.
} 


\section{Fungus}

METHODS

Conidia from 7-day cultures of Neurospora crassa, macroconidial wild-type Em 5297a, were washed and harvested as previously described (Richmond \& Somers, 1962). Cell walls were prepared by shaking dense spore suspensions with an equal volume of ballotini (no. 12) in a Mickle disintegrator, kept at $4^{\circ}$, for $10 \mathrm{~min}$. The centrifuged walls, free of whole cells, were washed 10 times with $10 \%(w / v)$ sucrose, 5 times with $0.9 \%(\mathrm{w} / \mathrm{v}) \mathrm{NaCl}$, and 5 times with water, following the technique of Dyke (1964). After disruption an appreciable proportion of the cell walls still retained the almost complete shape of the intact conidia and these walls were used for microelectrophoresis. Total lipid was determined by solvent extraction of dried cell walls (in vacuo over phosphorus pentoxide) with hot chloroform + methanol $(2+1, v / v)$ followed by hot ether.

Protoplasts were prepared by incubating young hyphae of Neurospora crassa with a Helix pomatia digestive-juice extract (L'industrie Biologique Française, Gennevilliers, France) as in the method of Kinsky (1962). The only amendment was that the final protoplast suspension was washed and stabilized in $0.58 \mathrm{M}$-sucrose maintained at $\mathrm{pH} 5.6$ with sodium acetate buffer of ionic strength 0.05 : at $4^{\circ}$ the protoplasts were stable for up to 2 days in this medium.

\section{Dodine acetate}

A sample, m.p. $134-135^{\circ}$, was prepared by ethanol-ether recrystallization from technical-grade material. Stock solutions made up in ethanol were diluted in the experimental aqueous solutions so that the final ethanol concentration was less than $2 \%$ (v/v). Radioactive dodine acetate, of specific activity $6 \mu \mathrm{c} / \mathrm{mg}$., labelled in the guanidine carbon with ${ }^{14} \mathrm{C}$, was generously supplied by American Cyanamid Co. Chemical analysis and radioassay of the dodine cation were carried out as before (Somers \& Pring, 1966).

\section{Micro-electrophoresis}

The electrophoretic mobilities of conidia, cell walls, and protoplasts-all usually at a concentration of $1 \mathrm{million} / \mathrm{ml}$.- were measured in a rectangular closed cell, airthermostatted at $25 \cdot 0 \pm 0 \cdot 2^{\circ}$, whose construction and operation is described by Gittens \& James (1960). The cell was mounted in the lateral position of Hartman, Bateman \& Lauffer (1952) and the symmetry checked. All subsequent measurements were made at the nearer stationary layer: human erythrocytes in $0.067 \mathrm{M}$-phosphate buffer (pH 7.35) were used to calibrate the cell (Gittens \& James, 1960). The conductivity of the buffered suspensions was measured at $25^{\circ}$, on a Wayne-Kerr B221 bridge. Movement was usually timed over $180 \mu$ in both directions (current reversal) and each mean mobility was obtained from at least 20 observations: the standard error of mean was less than $4 \%$.

Conidia, cell walls, and protoplasts were washed twice with the appropriate buffer before adding to the electrophoresis cell. All buffer solutions were used at a final ionic strength $(I)$ of 0.05 . The following buffer solutions were used for $\mathbf{p H} /$ mobility curves (Gittens \& James, 1963): below pH 2.6, $\mathrm{HCl}$ and $\mathrm{NaCl} ; \mathrm{pH} 2 \cdot 6-9 \cdot 6, \mathrm{NaCl}+$ sodium acetate + sodium barbiturate $+\mathrm{HCl}$; above $\mathrm{pH} 9 \cdot 6, \mathrm{NaCl}+$ sodium acetate + 
sodium barbiturate $+\mathrm{NaOH}$. All experiments with dodine acetate were carried out in sodium acetate buffer, $\mathrm{pH}$ 5.6: dodine acetate was added to the buffered suspensions and electrophoretic observations made within $5 \mathrm{~min}$.

\section{Treatments to modify the surface groups of Neurospora crassa}

Phosphatase. Washed conidia and cell walls were suspended in barbiturate buffer (pH 7.9, I 0.02) containing $0.0005 \%$ (w/v) alkaline phosphatase (E.C. 3.1.3.1, British Drug Houses Ltd.) at $37^{\circ}$ for $1 \mathrm{hr}$ (Hill, James \& Maxted, 1963), then centrifuged and washed twice in the final buffer solution.

1-Fluoro-2,4-dinitrobenzene (FDNB). Conidia were washed 3 times in Sorensen phosphate buffer ( $\mathrm{pH} 7 \cdot 0, I 0 \cdot 05)$, then suspended in a $0 \cdot 1 \%(\mathrm{v} / \mathrm{v})$ ethanolic FDNB solution containing $0.9 \%(\mathrm{w} / \mathrm{v})$ sodium bicarbonate (Gittens \& James, 1963). The suspension was agitated for $5 \mathrm{hr}$ at $25^{\circ}$ and the conidia subsequently washed 5 times with ethanol before washing with the final buffer solution. The acid hydrolysis, with constant-boiling $\mathrm{HCl}$, of the FDNB-treated conidia and subsequent paper chromatography of the hydrolysates followed the methods of Ingram \& Salton (1957).

Diazomethane. Washed cell walls were dried in vacuo over phosphorous pentoxide and methylated with diazomethane as described by Best \& Durham (1965): diazomethane was prepared from $N$-methyl- $N$-nitroso-p-toluenesulphonamide (De Boer \& Backer, 1954). Methylated and control cell walls were incorporated into $\mathrm{KBr}$ discs and the infra-red spectra recorded on a Perkin Elmer 237 spectrophotometer.

\section{Fungitoxicity of dodine acetate}

Fungicidal activity was determined by the method previously described (Richmond $\&$ Somers, 1962). The spores were incubated with various concentrations of dodine acetate for $30 \mathrm{~min}$. at $25^{\circ}$, washed twice, then diluted to $50,000 / \mathrm{ml}$. in $0.02 \%(\mathrm{w} / \mathrm{v})$ sucrose, and germination counts made after $18 \mathrm{hr}$ incubation in a moist chamber at $25^{\circ}$.

\section{RESULTS}

\section{Nature of the surface charges on Neurospora crassa conidia}

Many workers have shown that the changes in electrophoretic mobility of microorganisms with $\mathrm{pH}$, measured in buffers of constant ionic strength, can be interpreted in terms of the ionogenic groups present at the cell surface (see James, 1965). In the light of these earlier investigations the form of the mobility-pH curve for Neurospora crassa conidia (Fig. 1) suggests the presence of strongly acidic groups and free amino groups (which give rise to the point of inflection at $\mathrm{pH} 10$ ). Phosphate groups are indicated by a $\mathrm{pK}$ as low as $\mathbf{2 . 6}$ and confirmed by the displacement of the mobility-pH curve when conidia are treated with alkaline phosphatase (Fig. 1). The remaining negative groups after this treatment (pK 4) are probably carboxyl.

There was no evidence, however, that phosphate groups of $\mathrm{pK}$ 2-3 were present on the surface of washed cell walls (Fig. 2) and treatment of the walls with alkaline phosphatase did not alter the pK from 4. The mobility-pH plot in Fig. 2 shows that the amino groups-presumably from surface protein - were unaffected by the washing treatments. The total lipid content of the cell walls was $14 \%$, on a dry weight basis. Electrophoretic measurements on cell walls in the presence of the anionic sodium 
dodecyl sulphate (SDS) showed that some of this lipid was situated on the cell surface. In acetate buffer ( $\mathrm{pH} \mathrm{5.6,I} \mathrm{0.05)}$ the mobility of cell walls increased from -0.69 $\mu /$ sec. $/ \mathrm{V} . / \mathrm{cm}$. to $-1.23,-1.59$ and $-3.64 \mu / \mathrm{sec} . / \mathrm{V} . / \mathrm{cm}$. in the presence of $10^{-5}, 10^{-4}$ and $10^{-3}$ SDS, respectively.

The mobility towards the anode of Neurospora crassa conidia increased after treatment with FDNB, which is consistent with the removal of $-\mathrm{NH}_{3}{ }^{+}$groups (Fig. 1). The hydrolysis of FDNB-treated conidia followed by paper chromatographic analysis to identify the $\mathrm{N}$-terminal groups showed only two spots, corresponding to the DNP-derivatives of $\epsilon$-lysine and histidine.

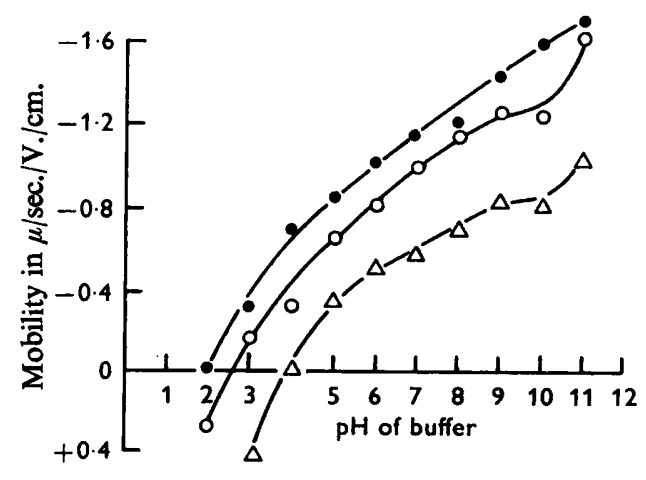

Fig. 1

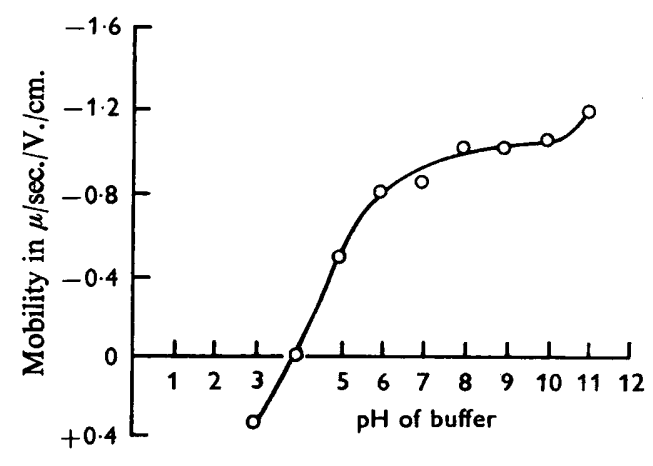

Fig. 2

Fig. 1. Electrophoretic mobility-pH curves for Neurospora crassa conidia. $\bigcirc$, Normal conidia; $\triangle$, conidia treated with phosphatase; $\bullet$, conidia treated with FDNB.

Fig. 2. Electrophoretic mobility-pH curve for Neurospora crassa cell walls.

Ionized carboxyl groups commonly make a major contribution to the negative electrophoretic mobility of micro-organisms (Douglas, 1959; James, 1965) and their presence at the surface of intact conidia and isolated cell walls has already been presumed from the results following phosphatase treatment. Confirmation has come from the infra-red spectrum of cell walls esterified with diazomethane. Figure 3 shows a pronounced shoulder at $1740 \mathrm{~cm} .^{-1}$ for treated walls (curve A) due to the carbonyl stretch of the ester: no such absorption was shown by cell walls subjected to the same preparative treatment, i.e. stirred in methanol-ether for $3 \mathrm{hr}$, but omitting diazomethane (curve B). Similar results-although with a less pronounced shoulder-have been reported for the bacteria Aerobacter aerogenes (Gittens \& James, 1963) and Bacillus subtilis cell walls (Best \& Durham, 1965).

\section{Effect of dodine acetate on Neurospora crassa mobility}

Figure 4 shows the changes in electrophoretic mobility of intact conidia and cell walls of Neurospora crassa on treatment with various concentrations of dodine acetate at $\mathrm{pH} 5 \cdot 6$ : the dry weight of cell walls, $8 \mu \mathrm{g} . / \mathrm{ml}$., corresponded to 1 million conidia $/ \mathrm{ml}$. The negative charge borne by the spores and cell walls was gradually reduced by the dodine cation until at $580 \mu \mathrm{M}$ for spores and $210 \mu \mathrm{M}$ for walls it was completely neutralized. At higher dodine acetate concentrations the spores became positively charged. Determinations of the fungicidal activity of dodine acetate showed 
that spores, at 1 million/ml., were completely killed after $30 \mathrm{~min}$. immersion in solutions of concentration above $17 \mu \mathrm{M}$, i.e. where no effect on the mobility of the spores was apparent; the ED 50 was at $5 \mu \mathrm{M}$. The uptake of dodine acetate by $N$. crassa spores is known to be very rapid (Somers \& Pring, 1966), so that the differences in duration between the fungicidal tests (i.e. $30 \mathrm{~min}$.) and the electrophoretic observations (i.e. up to $5 \mathrm{~min}$.) will not be significant.

When dodine acetate was added to Neurospora crassa protoplasts, stabilized in sucrose-acetate medium, there was a rapid reduction in electrophoretic mobility but no evidence of charge reversal (Fig. 5). Protoplasts are obviously much more sensitive to the fungicide than are conidia, for when conidia at the same concentration, i.e. 0.2 million $/ \mathrm{ml}$., were incubated with $0.4 \mu \mathrm{M}$-dodine acetate the mobility of the conidia was unaffected; in fact even at $4 \mu \mathrm{M}$ no significant reduction in conidial mobility occurred. The fungicidal ED50 for spores at $0.2 \mathrm{million} / \mathrm{ml}$. was $0.7 \mu \mathrm{M}$-dodine acetate.

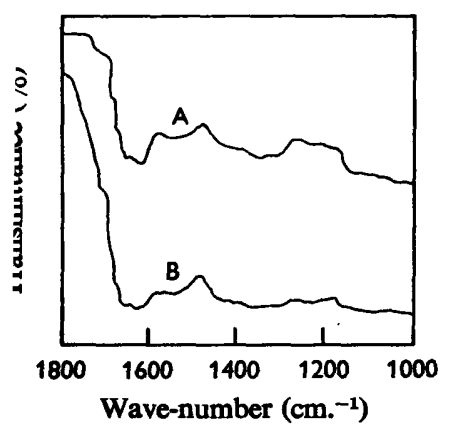

Fig. 3

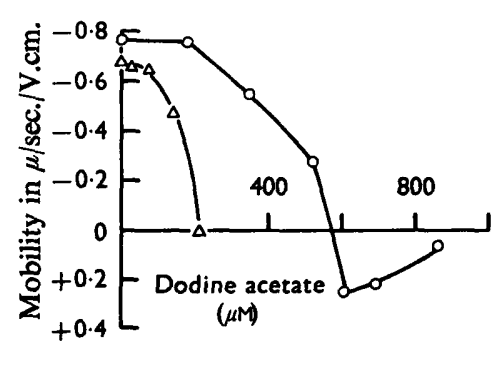

Fig. 4

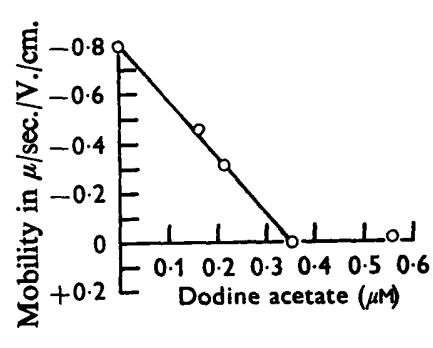

Fig. 5

Fig. 3. The infra-red spectra of Neurospora crassa cell walls. A, methylated with diazomethane; B, walls subjected to the same solvent and drying treatment as in A but diazomethane omitted.

Fig. 4. Effect of dodine acetate on the electrophoretic mobility of Neurospora crassa conidia and cell walls in acetate buffer (pH 5.6, I 0.05). $O$, Conidia (1 million/ml.); $\Delta$, cell walls $(8 \mu \mathrm{g} / \mathrm{ml}$.$) .$

Fig. 5. Effect of dodine acetate on the electrophoretic mobility of Neurospora crassa protoplasts $(0.2 \mathrm{million} / \mathrm{ml}$.) in $0.58 \mathrm{M}$-sucrose buffered with acetate to $\mathrm{pH} 5.6(\mathrm{I}, 0.05)$.

In the absence of dodine acetate the mobility of protoplasts in the sucrose-acetate medium was $-0.80 \mu / \mathrm{sec} . / \mathrm{V} . / \mathrm{cm}$., which corresponds to a mobility of $-1.6 \mu / \mathrm{sec} . / \mathrm{V} . / \mathrm{cm}$. in buffer alone, correcting for the dielectric constant and assuming a simple inverse relationship between mobility and viscosity with other factors such as particle charge and size remaining constant. The protoplasts are, of course, instantly lysed in the absence of sucrose but this rough calculation indicates that protoplasts carry a greater negative charge than conidia at the same $\mathrm{pH}$, i.e. $-0.75 \mu / \mathrm{sec} . / \mathrm{V} . / \mathrm{cm}$. for conidia (Fig. 1). Preferential adsorption of sucrose on to the protoplasts, which could decrease the ionogenic area, does not seem likely for there was little difference between the mobilities of protoplasts determined in sucrose-acetate in which the sucrose concentration ranged from 0.3 to $1.2 \mathrm{M}$.

Excess dodine acetate was incubated with protoplasts in the sucrose-acetate medium and, after washing, the protoplasts were completely lysed by transferring to distilled 
water. Table 1 shows that $30 \%$ of the accumulated dodine cation remained firmly bound to the protoplast membrane. It proved impossible to recover from the protoplast lysate more than a small fraction of the theoretical dodine cation content, presumably due to adsorption of the ion on the walls of the glass apparatus. Dodine cations accumulated by Neurospora crassa conidia have been found to be associated with cytoplasmic fractions of the cells (Somers \& Pring, 1966) and it is probable that the cell fraction sedimented at $10,000 \mathrm{~g}$-which had an appreciable dodine-binding capacity-contained cytoplasmic membrane fragments.

\section{Table 1. Binding of the dodine cation by Neurospora crassa protoplasts}

Protoplasts, at 7.2 million/ml., were incubated with $10 \mu \mathrm{M}-{ }^{14} \mathrm{C}$-labelled dodine acetate in $0.58 \mathrm{M}$-sucrose-acetate buffer (pH 5.6, I 0.05) for $30 \mathrm{~min}$. at $25^{\circ}$, then centrifuged out at $1500 \mathrm{~g}$ and washed twice in sucrose acetate. The washed protoplasts were suspended in distilled water and the membranes separated by centrifugation at $15,000 \mathrm{~g}$. The membranes were washed twice in water before radioassay.

Fraction

Washed intact protoplasts Protoplast membranes
Dodine cation content ( $\mu$ mole $/ 10^{3}$ million protoplasts)

$0 \cdot 17$

0.05

\section{DISCUSSION}

In principle the origin of surface charge on Neurospora crassa conidia may be due to fixed charges on the cell surface or to adsorbed ions. However, the chemical and enzymic treatments have established that amino, carboxyl, and phosphate groups are integral components of the spore surface and all contribute to the electrokinetic behaviour of the conidia. The surface amino groups have been identified as those of $\epsilon$-lysine and histidine and presumably form part of the protein complexes found in fungal cell wall preparations (Aronson, 1965). Carboxyl groups could originate from the polysaccharide matrix common to the walls of all micro-organisms whilst phosphate groups may be associated with the lipid and nucleic acid components of the $N$. crassa spore wall. It is noteworthy, however, that no acid phosphate groups were found on the surface of purified cell wall preparations, suggesting that the phosphate groups on the surface of intact conidia are removed by the intensive washing used to prepare clean walls. Eddy \& Rudin (1958), using a micro-electrophoresis technique, have found phosphate groups on the surface of both intact yeast cells and isolated walls, although it may be relevant that they washed cell walls with distilled water alone rather than with sucrose and $\mathrm{NaCl}$ as in the method of Dyke (1964). Certainly Harold \& Miller (1961) have shown that the association of polyphosphate with the cell wall of $N$. crassa mycelium is an artifact of the fractionation procedure.

Dyar \& Ordal (1946) and McQuillen (1950) have shown that cationic surface-active agents reduce the negative charge on bacteria and, with increasing concentration, completely neutralize the charge, finally reversing mobility to give a stabilized positive charge. Essentially the same pattern was observed for the interaction of dodine acetate with Neurospora crassa conidia. At pH 5.6 dodine acetate exists in solution as the positively charged dodine cation and this rapidly reacts with the surface carboxyl and phosphate groups of the spores: previous work has shown that the uptake of dodine cation by spores increases with increasing ionization of these groups (Somers \& Pring, 1966). The charge on the spores is probably not completely neutral- 
ized until they are saturated with the fungicide. After neutralization dodine cations can be held by van der Waals forces to surface lipid or the hydrocarbon chains of fixed dodine molecules so that a positive charge builds up on the spores. The decrease in positive charge at dodine acetate concentrations above $650 \mu \mathrm{M}$ (Fig. 4) supports a suggestion of McQuillen (1950) that concentric rings of surface-active agent are built up round the cell with polar groups facing alternately inward and outward.

The saturation level of dodine acetate bound by cell walls of Neurospora crassa has been shown to be some $16 \%$ of that retained by intact conidia (Somers \& Pring, 1966), hence the charges on cell walls are neutralized by much lower supernatant concentrations than are required for the conidia (Fig. 4). This earlier work also showed the fungicide to be strongly bound to cell walls and it is possible that the dodine molecules are incorporated, via their hydrocarbon group, within the lipid matrix of the cell wall. A wall lipid content of $14 \%$ is fairly high compared with the published values for yeasts and fungi (Phaff, 1963; Aronson, 1965) and the unwettable nature of $N$. crassa conidia suggests that some of the lipid is on the cell surface. Further confirmation of surface lipid has been given by the increased negative mobilities of walls treated with SDS: a result of reaction between surface lipid and the hydrophobic residues of the anionic agent which leaves the polar groups oriented towards the aqueous phase (James, 1965).

The protoplast membrane is apparently similar to other cytoplasmic membranes in consisting of a bimolecular leaflet of phospholipid coated with protein (Villanueva, 1966). The anionic carboxyl and phosphate groups at or near the cytoplasmic membrane of a fungal cell are considered to be binding sites for cationic fungicides (Somers, 1966) and it is probable that the same groups are present on the surface of a protoplast, especially in view of the high negative charge borne by protoplasts. The anionic charges on the protoplast surfaces are neutralized by much lower concentrations of dodine acetate than are required to kill conidia, which is consistent with the suggestion that reaction at the cell wall serves to detoxify some of the accumulated fungicide (Somers \& Pring, 1966).

The electrokinetic results presented provide no evidence that the toxic reaction between dodine acetate and Neurospora crassa conidia is located on the spore surface - the spores were completely killed before there was a perceptible reduction in mobility. The cytoplasmic membrane may be expected to be extremely vulnerable to the fungicide but toxicity cannot be adequately explained on the basis of physical disorganization of this membrane (Somers \& Pring, 1966). Enzyme inhibition at the cytoplasmic membrane or intracellular reaction still appear to be the most probable hypotheses to explain the fungitoxicity of dodine acetate.

We are indebted to Miss C. H. Slowley for providing fungal cultures and to Dr A. M. James for helpful discussions.

\section{REFERENCES}

Aronson, J. M. (1965). The cell wall. In The Fungi. Ed. by G. C. Ainsworth and A. S. Sussman, vol. 1, p. 49. New York: Academic Press.

Best, G. K. \& Durham, N. N. (1965). Vancomycin adsorption to Bacillus subtilis cell walls. Archs Biochem. Biophys. 111, 685.

De Boer, J. TH. \& BACKER, H. J. (1954). A new method for the preparation of diazomethane. Recl Trav. chim. Pays-Bas Belg. 73, 229. 
Douglas, H. W. (1959). Electrophoretic studies on bacteria. V. Interpretation of the effects of pH and ionic strength on the surface charge borne by $B$. subtilis spores with some observations on other organisms. Trans. Faraday Soc. 55, 850.

Douglas, H. W., Collins, A. E. \& Parkinson, D. (1959). Electric charge and other surface properties of some fungal spores. Biochim. biophys. Acta 33, 535.

DYAR, M. T. \& ORDAL, E. J. (1946). Electrokinetic studies on bacterial surfaces. I. The effects of surface-active agents on the electrophoretic mobilities of bacteria. J. Bact. 51, 149.

DYKE, K. G. H. (1964). The chemical composition of the cell wall of the yeast, Nadsonia elongata. Biochim. biophys. Acta 82, 374.

EDDY, A. A. \& Rudin, A. D. (1958). The structure of the yeast cell wall. I. Identification of charged groups at the surface. Proc. $R$. Soc. B 148, 419.

GitTENS, G. J. \& JAMES, A. M. (1960). An improved microelectrophoresis apparatus and technique for studying biological cell surfaces. Analyt. Biochem. 1, 478.

GitTENS, G. J. \& JAMES, A. M. (1963). Some physical investigations of the behaviour of bacterial surfaces. VI. Chemical modification of surface components. Biochim. biophys. Acta 66, 237.

Hannan, P. J. (1961). Electrophoretic properties of spores of Aspergillus niger. Appl. Microbiol. 9, 113.

HAROLD, F. M. \& Miller, A. (1961). Intracellular localization of inorganic polyphosphate in Neurospora crassa. Biochim, biophys. Acta 50, 261.

HaRTMAN, R. S., BATEMAN, J. B. \& LAUfFer, M. A. (1952). Electrophoresis by the microscope method: a simple experimental assembly. Archs Biochem. Biophys. 39, 56.

Hill, M. J., JAmes, A. M. \& MAXTED, W. R. (1963). Some physical investigations of the behaviour of bacterial surfaces. IX. Studies on the streptococcal cell wall. Biochim. biophys. Acta 75, 402.

INGRAM, V. M. \& SALTON, M. R. J. (1957). The action of fluorodinitrobenzene on bacterial cell walls. Biochim. biophys. Acta 24, 9.

JAMES, A. M. (1965). Surface-active agents in microbiology. Surface Activity and the Microbial Cell, p. 3, S.C.I. Monograph no. 19. London.

KINSKY, S. C. (1962). Effect of polyene antibiotics on protoplasts of Neurospora crassa. J. Bact. 83, 351.

MCQUILLEN, K. (1950). The bacterial surface. I. Effect of cetyl-trimethyl-ammonium bromide on the electrophoretic mobility of certain Gram-positive bacteria. Biochim. biophys. Acta 5, 463.

Phaff, H. J. (1963). Cell wall of yeasts. A. Rev. Microbiol. 17, 15.

RICHMOND, D. V. \& SOMERS, E. (1962). Studies on the fungitoxicity of captan. I. The structural specificity of captan and six $N$-trichloromethylthio analogues. Ann. appl. Biol. 50, 33.

Somers, E. (1966). The sites of reaction of fungicides in spores. In The Fungus Spore. Ed. by M. F. Madelin, p. 299. London: Butterworths.

Somers, E. \& Pring, R. J. (1966). Uptake and binding of dodine acetate by fungal spores. Ann. appl. Biol. 58, 457.

Villanueva, J. R. (1966). Protoplasts of fungi. In The Fungi, Ed. by G. C. Ainsworth and A. S. Sussman, vol. 2, p. 3. New York: Academic Press. 